\title{
Problems of Jordanian Public Universities' Students: A Survey Study
}

\author{
Saleh Salem Al-khawaldeh ${ }^{1} \&$ Soud Fahd Alkhrsha ${ }^{2}$ \\ ${ }^{1}$ Department of Educational Sciences, World Islamic Science\& Education University(WISE), \\ Amman, Jordan \\ *Correspondence: Department of Educational Sciences, World Islamic Science \& Education \\ University(WISE), P.O. Box: 1101 postal address: 11947, Amman, Jordan. E-mail: \\ president@wise.edu.jo
}

Received: June 9, 2015 Accepted: October 31, 2015 Published: December 30, 2015

doi:10.5296/ije.v7i4.7779 URL: http://dx.doi.org/10.5296/ije.v7i4.7779

\begin{abstract}
This study aims at identifying the types of problems encountered Jordanian Public UniversityStudents according to students themselves. It also seeks to investigate the effect of the variables of faculty, level of study, gender and academic achievement on the degree of the intensity of such problems. For this purpose, a version of Moony checklist for problems student, adapted by Sowanah (1983), was used; it consists of (190) items classified into six domains. The sample of the study was randomly selected and consists of (406) male and female students.

The results of the study revealed that Jordanian Public University Students suffer from problems in all six domains. They are arranged in descending order according to degree of intensity as follows: Curricula and Methods of Instruction and adapting to University Life, Social and Recreational Activity, Health and Physical Growth, Home and Family Personal and Psycho-affective Relationships, Financial Position and vocational. No statistically significant difference $(\mathrm{a}=0.05)$ in the degree of the problems intensity attributed to the variables of students' faculty, level of study, gender or academic achievement was indicated. Results also revealed a positive attitude of the students towards the counseling services available to them and that they felt they need the same counseling services in all the study domains with no statistically significant difference $(a=0.05)$ attributed to any of the study variables. The researchers recommended an establishment of a counseling center in order to help the students overcome their problems.
\end{abstract}

Keywords: problems, public university, Jordanian Students 


\section{Background \&Significance}

The youth in any nation are the real mirror that reflects the society reality and its development as they represent the attitude towards the future for its age, therefore nations have paid attention to this category giving it much care and more training as a necessity for the individual ' $\mathrm{s}$ interest who owns skills that need development and as a social and economic necessity because the powerful society needs a generation capable to work and stand in front of the great challenges facing the society in this dangerous and sensitive period of time in our history(Rizq, 2008, 14).

The university life for the youth is considered an important stage in forming his character. The university as an independent educational institution represents a rich experience and it causes problems and pressures that affect negatively the youth character; they suffer from depression, low achievement, lack of confidence in addition to lack of concentration towards issues facing them at their university life or in their personal life (Sa `ada, et.al, 2002, p2).

University stage needs adaptation and compatibility (Adas\&Toq, 1996) as there are many problems and social, educational and emotional needs facing the students in addition to academic problems and others that affect the social, academic and social future of the individual (Hatab\&Maki, 1980).

The university society lives in a social environment includes a group of people who are close in age for a long time so the student's adaptation in this society is considered one of the aspects of his general adaptation. His satisfaction of the quality of the university life could affect his achievement (Senile \& et al, 2001, 11-52).

Al-tal \& Bolbol assure that university is a new experience to the students and it differs from their previous experiences as it has many and new problems and experiences which they should over come and adapt to them. Some of these problems are: identifying the university's regulations, choosing the major, the capability to make decisions concerning the future career and the scientific life (Al-tal \& Bolbol, 1988, 128-129).

The students also face problems that hinder their adaptation and the university's achievement of its goals in building the student scientifically and developing his character as the psychological problems; lack of self confidence, anxiety, the social problems as difficulty in creating positive relations with the other students and academic staff in addition to academic problems as low achievement, choosing the major, utilizing time, using library, writing reports and research(Hamdi,1988,476).

Oweida points that students in the university life try harder to create new identities in the new environment and this change in identities requires an effective and compatible process that enable them to be adapt to this change gradually especially one of the basic psychological challenges facing them is the compatibility with feeling of loss when they leave their identities to have new ones(Oweida,2005,91-110).

Heppner \&et al (1984) pointed that the psychological stress and adaptation difficulties are the outcomes of the inactive method followed by the students in solving the problems and so the 
university students according to their age, their need to prove themselves, and achieve a degree of independency face great burdens in addition to their homework and the problems they face socially, or economically.

And because the student is the core of the academic process in the higher education, guiding him correctly and meeting his needs is the key of his success and this is possible through psychological care and the appropriate social and educational counseling by knowing the student's developmental characteristics.

Knowing there is a high correlation between the students' attitudes towards counseling and their university adaptation, we realize the importance of finding the counseling needs that the students need to evaluate the necessity of establishing a center of counseling and psychological services so as to help the students to deal with the problems and to achieve compatibility between individual and social levels in addition to help them to continue their academic studies successfully(Morgan,2003).

Based on what was mentioned, the university students face many problems that they should identify and know adaptation methods to them so as they can deal with the possible psychological effects and pressures for these problems.

In the same context, many studies were conducted to identify the universities students' problems as:

The study of Abo alia \& Mahafda (1997)aimed to identify the problems of Hashemite university's students. A questionnaire including 41 items distributed to 4 fields was applied on a sample consisted of 235 male and female students. Results revealed the problems facing students: university services, relations with the academic staff, learning skills, academic adaptation. Moreover, results showed statistical significant differences attributed to gender as the males suffered more than the females from academic services while there were no statistical significant differences attributed to college variable or the interaction between the gender and college.

Murray's study (1990) compared between the student who enrolled the university directly after finishing the high school and those who enrolled university after years of finishing high school. Results showed the major problems facing the students related to the academic field and the learning skills. The two groups face problems in writing and time management and they do not have realistic expectations about achievement level and the major causes for the first year's students' pressures and anxiety are: unrealistic expectations, lack of participation in the academic life and low achievement. Additionally, there were no real differences between the students who enroll the university directly after high school or after a while in the problems facing them.

While the study of Mosharaf(2000) aimed to identify the most important problems facing the students. The sample of the study consisted of 257 students of Sana' University. The researcher used a list of university students' problems and their counseling needs. Results showed the university students have many problems concerning the counseling field, the academic field, psychological, social and healthy fields. Results also showed statistical significant differences 
in the counseling and academic fields between the students with scientific specializations and the students with literary specializations in favor of the students with scientific specializations. Additionally, there statistical significant differences between the male and the females in favour of the males. There were also statistical significant differences between the first year students and the fourth year students in the health field in favor of the fourth year students.

Al-najm's study(2002) aimed to identify the problems facing the students of Education college at University of King Faisal according to gender, specialization, and academic level. The study used the descriptive approach and the questionnaire as an instrument. Results revealed the most significant problems were ignoring the students' complaints, not taking into account the students' circumstances in preparing the exams schedule, the crowded classes, lack of democratic atmosphere in dealing with the students, lack of the objectivity of the exams' results. There were differences between the male and female students regarding not taking into account their circumstances, ignoring the students' complaints. The computers' errors in registration process, the curricula's lack of ability to develop thinking and the skill.

The study of Banna\&Ribi (2006) aimed at identifying Al-Aqsa University's students' common problems and suggesting solutions to reduce the degree of these problems through using a questionnaire consisted of 70 items divided to five fields and distributed to 200 male and female students. Results showed the problems were arranged as follows from the perspective of the respondents: academic building, educational problems, psychological problems, ethic and social problems and sexual ones. Results also revealed lack of statistical significant differences attributed to specialization while there were statistical significant differences attributed to gender in the ethic, social and sexual problems in favour the males and in the educational problems in favour of the females. Additionally, there were differences attributed to the year in the sexual dimension in favour of the first year students compared with the second and third year students.

The study of Morgans(2003) aimed at identifying the relation between the students' attitudes towards academic counseling and their university adaptation. The sample of the study consisted of 610 male and female students of Orleans University. Results revealed s strong correlation between the students' attitudes towards academic counseling and university adaptation and there were differences between the students in public and private universities' students in their attitudes towards academic counseling in favour the students of the public universities.

The study of Lucas\&Barkly(2005) aimed at studying the students who faced problems and looked for academic counseling at Johns Hopkins University in USA. The sample of the study consisted of 597 male and female students; 12\% were African, 9\% were Asian and the rest were white. Results showed the African students faced obstacles and problems when following up their job goals compared with other students whereas the Asian suffered from psychological problems. Results also showed anxiety and depression were higher in females compared with the males as they suffered in their careers.

And Sheen's study(2009) aimed to identify the students' problems of Open Jerusalem University according to gender and age category variables so as to evaluate their counseling 
needs to have counseling services provide support to the students and to alleviate the degree of the problems they face. A questionnaire was developed and distributed to 613 students. Results showed the students' problems represented by inconvenient atmosphere for exams and studying, the supervisor's ignorance to his role in facilitating the use of university courses and the requirements of increasing the students' motivation in addition to the shortage in the support psychological counseling services that help in increasing the degree of students' adaptation. The students' problems in the academic and psychological fields were higher within the age category (30 and more).

We can concluded from the previous studies the following:

- The university students face many problems during the studying stages as academic, adapting, social and emotional problems.

- The students' problems have increased since the 1990s.

Therefore, the researchers expect that the students face many problems in the Jordanian public universities in general and they should be identified. Also, the researchers expect that the students need counseling services to help them to face these problems and to achieve higher degree of social, academic and psychological compatibility through their university life.

\section{Problem of the Study \&Its Questions}

Leaving high school to the university is considered a critical period of time in the student's life that includes many problems representing by facing difficulties in adaptation because the student in this stage has to make decisions related to his future and academic life as choosing his major, method of studying, doing his assignments, and other decisions concerning his social life and his relation with friends, expressing his opinions in addition to forming cultural, political ,academic and personal attitudes.

During the researcher's work as a member in the academic staff in (WISE), he noticed the students' complaints about some cases and their try to look for help from different parts: academically, psychologically and socially. The researchers expect many problems facing the students so there is a need to identify them and work on planning the appropriate counseling services and presenting them in the suitable time.

Therefore, the study aims to identify the Jordanian public universities' students' problems by answering the following questions:

1. What are the most significant problems facing the students of Jordanian public universities?

2. Does the level of every problem which the Jordanian public universities' students suffer from differ according to the college, university level, gender and achievement variables?

\section{Significance of the study}

1. Enrich the studies related to adaptation problems facing students in many universities. 
2. Identify and record problems facing Jordanian universities students to send them to decision makers to enable them to identify counseling needs for solving students' problems.

3. Provide basic information to decision makers about some basic psychological components of the students in the Jordanian public universities which may help in providing counseling services based on their needs and priorities.

\section{Limitations of the study}

The study was limited to the students of the Jordanian public universities and it was applied in the second semester for the academic year 2013-2014. The study was also limited to the instrument used.

\section{Procedural definitions}

The students: the students of the scientific and human colleges in the Jordanian public universities.

Students' problems: difficulties that students face in specific situations where they were unable to take appropriate decisions which make them uncomfortable (Kayed, 1995). And the researcher defines them procedurally as the ratio of the of the problems spread among the respondents through their responses.

\section{Population \&sample of the study}

The population of the study 1 consisted of all the students of the Jordanian public universities in the year 2013-2014 while the sample of the study which was selected randomly consisted of 406 male and female students who are enrolled in the universities in the second semester for the academic year 2013-2014 and the following table illustrates the distribution of the sample according to the study's variables.

Table 1. Distribution of the sample according to University, gender, college, year and academic achievement variables

\begin{tabular}{cccc}
\hline Variable & Category & $\mathrm{N}$ & Ratio \\
\hline \multirow{3}{*}{ University } & WISE & 178 & $43.8 \%$ \\
& Yarmouk & 121 & $29.8 \%$ \\
Gender & Mo`tah & $\mathrm{M}$ & $26.4 \%$ \\
& Male & 152 & $37.2 \%$ \\
College & Female & 254 & $62.8 \%$ \\
& Human & 283 & $69.7 \%$ \\
\multirow{3}{*}{ Achievement } & Scientific & 123 & $30.3 \%$ \\
& Low & 212 & $52.2 \%$ \\
& Moderate & 125 & $30.8 \%$ \\
& High & 69 & $17.0 \%$ \\
Level & First & 92 & $22.7 \%$ \\
& Second & 135 & $33.3 \%$ \\
& Third & 77 & $19.0 \%$ \\
& Fourth & 102 & $25.1 \%$ \\
\hline
\end{tabular}




\section{Macrothink}

\section{Instrument of the study}

The instrument consists of two parts: the first includes information concerning the study's variables: college, gender, achievement, university while the second part which includes a developed questionnaire to control the students' problems at the university consists of 190 items distributed into 6 fields that represent many problems as follows:

First field: curricula and teaching methods and their appropriateness to academic life (45 problems).

Second field: personal, emotional and psychological relations (47 items)

Third field: financial, living and professional status (38 items)

Fourth field: health and physical growth (19 items)

Fifth field: social and entertainment activity (19 items)

Sixth field: family (22 items)

These items were built after reviewing the theoretical literature concerning the students' problems in different universities.

\section{Instrument validity}

The instrument validity was checked by presenting it to a group of arbitrators who are specialized in the Jordanian universities. The initial copy of the instrument consisted of 209 items but after taking the arbitrators' notes into account 14 items were deleted,5 items were adjusted linguistically. So the final copy of the instrument consisted of 190 items.

The instrument reliability

The researchers calculate the internal consistency coefficient of Cronbach Alpha and the reliability coefficient was 0.88 which is considered acceptable for the study and the following table illustrates the reliability coefficients.

Table 2. Reliability Coefficients of the fields

\begin{tabular}{llr}
\hline $\mathrm{N}$ & \multicolumn{1}{c}{ Problems } & Cronbach Alpha \\
\hline 1 & curricula and teaching methods and their appropriateness to academic life & 0.80 \\
2 & personal, emotional and psychological relations & 0.87 \\
3 & financial, living and professional status & 0.85 \\
4 & health and physical growth & 0.83 \\
5 & social and entertainment activity & 0.81 \\
6 & Family & 0.85 \\
Total degree & 0.88 \\
\hline
\end{tabular}

Variables of the study

1- Independent variables 
a) Gender (male, female

b) College (human, scientific)

c) Academic level(first, second, third and fourth year )

d) Achievement: low (average less than 69\%), moderate(average between 69\% -79\%, high (average more than $80 \%$ )

Dependent variables: the students' responses on the scale of the problems concerning curricula and teaching methods and their appropriateness to academic life, personal ,emotional and psychological relations, financial ,living and professional status, health and physical growth, social and entertainment activity and family .

Statistical treatment: to answer the study's questions, the following were used: means and standard deviations in addition to T test, ANOVA and Scheffe' Test.

\section{Results \&Interpretation}

First: results concerning the first question: "What are the most significant problems which the Jordanian public universities' students face?. To answer this question, the means and the standard deviations were calculated as it is illustrated in table (3).

Table 3. Means \& standard deviations for the most significant problems facing the students arranged ascending

\begin{tabular}{lrrrr}
\hline $\mathrm{N}$ & \multicolumn{1}{c}{ Problems } & $\mathrm{M}$ & Std RANK & Degree \\
\hline 3 financial ,living and professional status & 3.630 .42 & 1 & Moderate \\
1 curricula and teaching methods and their appropriateness to academic life & 3.340 .41 & 2 & Moderate \\
2 personal ,emotional and psychological relations & 3.280 .39 & 3 & Moderate \\
6 Family & 3.100 .51 & 4 & Moderate \\
4 health and physical growth & 3.090 .59 & 5 & Moderate \\
5 social and entertainment activity & 3.080 .57 & 6 & Moderate \\
\multicolumn{2}{c}{ Total degree } & 3.300 .33 & Moderate \\
\hline
\end{tabular}

It is clear from the previous table that the degrees of the most significant problems facing Jordanian university students were in general moderate as the total mean was (3.30) and std (0.33). Additionally, the means of the problems ranged from 3.08 to -3.63 ) and in the first rank came the field: "financial ,living and professional status", with a mean 3.63 and std (0.42).And this result may attribute to the students' great interest in the academic aspects and the problems facing him during the his studying .moreover, the problems concerning achievement, academic staff, curricula and teaching methods used in the universities and the students ability is limited facing the continuous increase in the academic tuition fees. The academic life becomes difficult in the current economic situation; the text book becomes a 
burden in addition to the crowded classes which make the students feel upset of the mess. In the second rank came the field: "curricula and teaching methods and their appropriateness to academic life", with a mean (3.34) and std (0.41) and this result may due to different reasons as: instructors' absence, many researches to be done by the students, multi plans in the departments, in addition to lack of textbook.

In the third rank came the field: "personal,emotional and psychological relations" with a mean (3.28) and standard deviation (0.39) and this result may attribute to the psychological feelings that students suffer from in light of the psychological problems they face these days.while the field: "family" came in the fourth rank with a mean (3.10) and standard deviation (0.51) followed respectively by the fields: "health and physical growth" with a mean (3.09) and standard deviation (0.59) and "social and entertainment activity" with a mean (3.08) and standard deviation (0.57).

Second: results concerning the second question: Does the level of the problems which the students face vary according to study's variables: gender, college, university year and theachievement? The answer was as following:

1. Gender variable: means and standard deviations of the level of the problems which the Jordanian university students' face and T test was used as it is illustrated in table 4.

Table 4. Means and standard deviations and $T$ test for independent samples for the differences in the level of problems which the students face according to the gender

\begin{tabular}{lcc}
\hline \multicolumn{1}{c}{ Problems } & College N M Std T value Sig. \\
\hline curricula and teaching methods and their appropriateness to academic life & Male $1513.260 .35-2.7960 .005$ \\
personal ,emotional and psychological relations & Female 2543.380.44 \\
financial ,living and professional status & Male $1513.210 .34-2.9510 .003$ \\
& Female 2543.320.40 \\
health and physical growth & Male $1513.570 .40-2.4400 .015$ \\
& Female 2543.670.42 \\
social and entertainment activity & Male $1512.980 .54-2.7590 .006$ \\
& Female 2543.150.61 \\
Family & Male $1513.010 .52-1.7980 .073$ \\
Total degree & Female 2543.120.58 \\
\hline
\end{tabular}

Results in table (4) showed statistical significant differences at $(a \leq 0.05)$ in the level of the problem facing the Jordanian universities' students according to the gender variable as calculate $\mathrm{T}$ value was $(-3.559)$ with $\operatorname{sig}(0.000)$ for the total degree and there were statistical significant differences at $(\mathrm{a} \leq 0.05)$ in the level of the problem facing the Jordanian universities' students according to the gender variable in all the fields except the field of 
"social and entertainment activity" and the difference was in favour of the females and this result may attribute to the females' high feeling of the problems and they have more courage to review the educational issues from different sides.

2. College variable: means and standard deviations were calculated of the level of the problems facing the Jordanian universities' problems. T test was also to examine the differences according to college variable as it is illustrated in table 5 .

Table 5. Means \&standard deviations and T test of the level of the Jordanian universities' students' problems according to the college variable

\begin{tabular}{|c|c|c|c|c|c|c|}
\hline Problems & College & $\mathrm{N}$ & M & Std & $\mathrm{T}$ & Sig. \\
\hline curricula and teaching methods and their appropriateness to academic life & $\begin{array}{l}\text { Human } \\
\text { Scientific }\end{array}$ & 283 & $\begin{array}{l}3.31 \\
3.41\end{array}$ & \multicolumn{3}{|c|}{$\begin{array}{l}0.41-2.3500 .019 \\
0.40\end{array}$} \\
\hline personal, emotional and psychological relations & $\begin{array}{l}\text { Human } \\
\text { Scientific }\end{array}$ & $\begin{array}{l}283 \\
123\end{array}$ & $\begin{array}{l}3.26 \\
3.33\end{array}$ & \multicolumn{3}{|c|}{$\begin{array}{l}0.38-1.7390 .083 \\
0.39\end{array}$} \\
\hline financial ,living and professional status & $\begin{array}{l}\text { Human } \\
\text { Scientific }\end{array}$ & 283 & $\begin{array}{l}3.61 \\
3.68\end{array}$ & \multicolumn{3}{|c|}{$\begin{array}{l}0.42-1.5880 .113 \\
0.41\end{array}$} \\
\hline health and physical growth & $\begin{array}{l}\text { Human } \\
\text { Scientific }\end{array}$ & 283 & $\begin{array}{l}3.08 \\
3.11\end{array}$ & \multicolumn{3}{|c|}{$\begin{array}{l}80.59-0.4580 .647 \\
10.58\end{array}$} \\
\hline \multirow[t]{3}{*}{ social and entertainment activity } & $\begin{array}{l}\text { Human } \\
\text { Scientific }\end{array}$ & $\begin{array}{l}283 \\
123\end{array}$ & $\begin{array}{l}3.04 \\
3.19\end{array}$ & \multicolumn{3}{|c|}{$\begin{array}{l}0.55-2.526 \\
0.59\end{array}$} \\
\hline & $\begin{array}{l}\text { Human } \\
\text { Scientific }\end{array}$ & $\begin{array}{l}283 \\
123\end{array}$ & & \multicolumn{3}{|c|}{$\begin{array}{l}0.51-0.6010 .548 \\
0.52\end{array}$} \\
\hline & $\begin{array}{l}\text { Human } \\
\text { Scientific }\end{array}$ & $\begin{array}{l}283 \\
123\end{array}$ & $\begin{array}{l}3.28 \\
3.36\end{array}$ & \multicolumn{3}{|c|}{$\begin{array}{l}0.32-2.2440 .025 \\
0.33\end{array}$} \\
\hline
\end{tabular}

Results in the previous table showed statistical significant differences at $(a \leq 0.05)$ in the level of the problems which the Jordanian students suffer from according to the college variable where calculated $\mathrm{T}$ value was $(-2.244)$ with sig $(0.025)$ for the total degree and there were statistical significant differences at $(a \leq 0.05)$ in the level of the problems which the Jordanian students suffer from according to the college variable in the followings fieldscurricula and teaching methods and their appropriateness to academic life andsocial and entertainment activity in favor the scientific colleges and this result may due to the fact that students of scientific colleges whose average is high look for higher degree of satisfaction. While there were no statistical significant differences concerning theother problems and this result may attribute to the generality of the problems as the whole students suffer from the same problems for living in similar environments.

University year: means and standard deviations were calculated of the level of the problems facing the Jordanian universities' problems according to the university year variable as it is illustrated in table 6 . 
Table 6. Means and standard deviations were calculated of the level of the problems facing the Jordanian universities' problems according to the university year variable

\begin{tabular}{|c|c|c|c|c|}
\hline Field & Year & $\mathrm{N}$ & M & Std \\
\hline \multirow[t]{5}{*}{$\begin{array}{l}\text { curricula and teaching methods and their } \\
\text { appropriateness to academic life }\end{array}$} & $1^{\text {st }}$ & 92 & 3.56 & 0.41 \\
\hline & $2^{\text {nd }}$ & 135 & 3.18 & 0.41 \\
\hline & $3^{\text {rd }}$ & 77 & 3.38 & 0.29 \\
\hline & $4^{\text {th }}$ & 102 & 3.31 & 0.39 \\
\hline & Total & 406 & 3.34 & 0.41 \\
\hline \multirow[t]{5}{*}{ personal, emotional and psychological relations } & $1^{\text {st }}$ & 92 & 3.46 & 0.36 \\
\hline & $2 \mathrm{~d} \mathrm{n}$ & 135 & 3.13 & 0.38 \\
\hline & $3^{\text {rd }}$ & 77 & 3.38 & 0.38 \\
\hline & $4^{\text {th }}$ & 102 & 3.24 & 0.33 \\
\hline & Total & 406 & 3.28 & 0.39 \\
\hline \multirow[t]{5}{*}{ financial ,living and professional status } & $1^{\text {st }}$ & 92 & 3.80 & 0.41 \\
\hline & $2^{\text {nd }}$ & 135 & 3.57 & 0.45 \\
\hline & $3^{\mathrm{rd}}$ & 77 & 3.63 & 0.30 \\
\hline & $4^{\text {th }}$ & 102 & 3.57 & 0.43 \\
\hline & Total & 406 & 3.63 & 0.42 \\
\hline \multirow[t]{5}{*}{ health and physical growth } & $1^{\text {st }}$ & 92 & 3.16 & 0.56 \\
\hline & $2^{\text {nd }}$ & 135 & 3.03 & 0.66 \\
\hline & $3^{\text {rd }}$ & 77 & 3.23 & 0.57 \\
\hline & $4^{\text {th }}$ & 102 & 2.99 & 0.49 \\
\hline & Total & 406 & 3.09 & 0.59 \\
\hline \multirow[t]{6}{*}{ social and entertainment activity } & $1^{\mathrm{st}}$ & 92 & 3.39 & 0.59 \\
\hline & $2^{\text {nd }}$ & 135 & 2.78 & 0.46 \\
\hline & $3^{\text {rd }}$ & 77 & 3.21 & 0.45 \\
\hline & $4^{\text {th }}$ & 102 & 3.12 & 0.56 \\
\hline & Total & 406 & 3.08 & 0.57 \\
\hline & $1^{\text {st }}$ & 92 & 3.32 & 0.57 \\
\hline \multirow{6}{*}{ Family } & $2^{\text {nd }}$ & 135 & 3.04 & 0.49 \\
\hline & $3^{\text {rd }}$ & 77 & 3.10 & 0.41 \\
\hline & $4^{\text {th }}$ & 102 & 2.96 & 0.49 \\
\hline & Total & 406 & 3.10 & 0.51 \\
\hline & $1^{\text {st }}$ & 92 & 3.50 & 0.32 \\
\hline & $2^{\text {nd }}$ & 135 & 3.17 & 0.31 \\
\hline \multirow{3}{*}{ Total degree } & $3^{\mathrm{rd}}$ & 77 & 3.37 & 0.25 \\
\hline & $4^{\text {th }}$ & 102 & 3.25 & 0.31 \\
\hline & Total & 406 & 3.30 & 0.33 \\
\hline
\end{tabular}

It is clear from the previous table that there were apparent differences between the means of the level of the problems which the Jordanian students suffer from according to the university 
year variable as the first year students got the highest mean (3.50) followed respectively by the third year students with( 3.37), and the second year students with (3.17). And to determine whether the differences between the means were statistically significant or not at $(a \leq 0.05)$, ANOVA was used and its results were as follows:

Table 7. ANOVA for the differences in the level of the problems which the Jordanian public universities' students suffer from according to the level of year variable

\begin{tabular}{|c|c|c|c|c|c|c|}
\hline Field & Source of variance & $\begin{array}{l}\text { Sum of } \\
\text { seq. }\end{array}$ & $\mathrm{Fd}$ & $\begin{array}{l}\text { M of sum of } \\
\text { seq. }\end{array}$ & $\mathrm{F}$ & Sig. \\
\hline \multirow{3}{*}{$\begin{array}{l}\text { curricula and teaching methods and } \\
\text { their appropriateness to academic life }\end{array}$} & Between the groups & 8.528 & 3 & 2.843 & \multirow{3}{*}{\multicolumn{2}{|c|}{19.1170 .000}} \\
\hline & Within the groups & 59.777 & 402 & 0.149 & & \\
\hline & Total & 68.305 & 405 & & & \\
\hline \multirow{3}{*}{$\begin{array}{l}\text { personal ,emotional and psychological } \\
\text { relations }\end{array}$} & Between the groups & 6.818 & 3 & 2.273 & \multirow{3}{*}{\multicolumn{2}{|c|}{17.1390 .000}} \\
\hline & Within the groups & 53.308 & 402 & 0.133 & & \\
\hline & Total & 60.127 & 405 & & & \\
\hline \multirow[t]{3}{*}{ financial ,living and professional status } & Between the groups & 3.609 & 3 & 1.203 & \multirow[t]{3}{*}{7.141} & 0.000 \\
\hline & Within the groups & 67.713 & 402 & 0.168 & & \\
\hline & Total & 71.322 & 405 & & & \\
\hline \multirow[t]{3}{*}{ health and physical growth } & Between the groups & 3.588 & 3 & 1.196 & \multirow[t]{3}{*}{3.539} & 0.015 \\
\hline & Within the groups & 135.854 & 402 & 0.338 & & \\
\hline & Total & 139.442 & 405 & & & \\
\hline \multirow[t]{9}{*}{ social and entertainment activity } & Between the groups & 22.943 & 3 & 7.648 & \multirow{3}{*}{\multicolumn{2}{|c|}{28.8060 .000}} \\
\hline & Within the groups & 106.727 & 402 & 0.265 & & \\
\hline & Total & 129.67 & 405 & & & \\
\hline & Between the groups & 7.025 & 3 & 2.342 & \multirow[t]{3}{*}{9.515} & 0.000 \\
\hline & Within the groups & 98.932 & 402 & 0.246 & & \\
\hline & Total & 105.957 & 405 & & & \\
\hline & Between the groups & 6.433 & 3 & 2.144 & \multirow[t]{3}{*}{23.379} & 0.000 \\
\hline & Within the groups & 36.873 & 402 & 0.092 & & \\
\hline & Total & 43.306 & 405 & & & \\
\hline
\end{tabular}

Results showed statistical significant differences at $(a \leq 0.05)$ in the level of the problems which the Jordanian university students suffer from according to the university year variable where calculated F was (23.379) with $\operatorname{sig}(0.000)$ to the total degree. Moreover, there were statistical significant differences at $(\mathrm{a} \leq 0.05)$ in the level of the problems which the Jordanian students suffer from according to the university year variable in all fields as $\mathrm{F}$ value was statistically significant. And to identify the significance of the differences, Sheffee post comparisons was used and the following table illustrated the results. 


\section{Macrothink}

Table 8. Sheffee post comparisons of the differences in the level of the problems facing the Jordanian public universities' students according to the year level

\begin{tabular}{|c|c|c|c|c|c|c|}
\hline Field & \multirow{2}{*}{ Year } & \multirow{2}{*}{$\mathrm{M}$} & $1^{\text {st }}$ & $3^{\text {rd }}$ & $4^{\text {th }}$ & $2^{\text {nd }}$ \\
\hline \multirow{5}{*}{$\begin{array}{l}\text { curricula and teaching } \\
\text { methods and their } \\
\text { appropriateness to } \\
\text { academic life }\end{array}$} & & & 3.56 & 3.38 & 3.31 & 3.18 \\
\hline & Ist & 3.56 & - & & & $*$ \\
\hline & $3^{\text {rd }}$ & 3.38 & & - & & \\
\hline & $4^{\text {th }}$ & 3.31 & & & - & \\
\hline & $2^{\text {nd }}$ & 3.18 & & & & - \\
\hline \multirow{6}{*}{$\begin{array}{l}\text { personal ,emotional and } \\
\text { psychological relations }\end{array}$} & I ourl & $M$ & $1^{\mathrm{st}}$ & $3^{\mathrm{rd}}$ & $4^{\text {th }}$ & $2^{\text {nd }}$ \\
\hline & Level & M & 3.46 & 3.38 & 3.24 & 3.13 \\
\hline & $1^{\text {st }}$ & 3.46 & - & & & $*$ \\
\hline & $3^{\text {rd }}$ & 3.38 & & - & & \\
\hline & $4^{\text {th }}$ & 3.24 & & & - & \\
\hline & $2^{\text {nd }}$ & 3.13 & & & & - \\
\hline \multirow{6}{*}{$\begin{array}{l}\text { financial ,living and } \\
\text { professional status }\end{array}$} & I eyel & $M$ & $1^{\mathrm{st}}$ & $3^{\mathrm{rd}}$ & $2^{\text {nd }}$ & $4^{\text {th }}$ \\
\hline & Lever & 10 & 3.80 & 3.63 & 3.57 & 3.57 \\
\hline & $1^{\mathrm{st}}$ & 3.80 & - & & & $*$ \\
\hline & $3^{\text {rd }}$ & 3.63 & & - & & \\
\hline & $2^{\text {nd }}$ & 3.57 & & & - & \\
\hline & $4^{\text {th }}$ & 3.57 & & & & - \\
\hline \multirow{6}{*}{$\begin{array}{l}\text { health and physical } \\
\text { growth }\end{array}$} & Vo & M & $3^{\text {rd }}$ & $1^{\text {st }}$ & $2^{\text {nd }}$ & $4^{\text {th }}$ \\
\hline & Y ear & M & 3.23 & 3.16 & 3.03 & 2.99 \\
\hline & $3^{\text {rd }}$ & 3.23 & - & & & $*$ \\
\hline & $1^{\text {st }}$ & 3.16 & & - & & \\
\hline & $2^{\text {nd }}$ & 3.03 & & & - & \\
\hline & $4^{\text {th }}$ & 2.99 & & & & - \\
\hline \multirow{8}{*}{$\begin{array}{l}\text { social and entertainment } \\
\text { activity }\end{array}$} & & & $1^{\text {st }}$ & $3^{\text {rd }}$ & $4^{\text {th }}$ & $2^{\text {nd }}$ \\
\hline & Year & $\mathrm{M}$ & 3.39 & 3.21 & 3.12 & 2.78 \\
\hline & $1^{\text {st }}$ & 3.39 & - & & & $*$ \\
\hline & $3^{\text {rd }}$ & 3.21 & & - & & \\
\hline & $4^{\text {th }}$ & 3.12 & & & - & \\
\hline & $2^{\text {nd }}$ & 2.78 & & & & - \\
\hline & Vort & 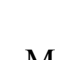 & $1^{\text {st }}$ & $3^{\mathrm{rd}}$ & $2^{\text {nd }}$ & $4^{\text {th }}$ \\
\hline & Year & $\mathrm{M}$ & 3.32 & 3.10 & 3.04 & 2.96 \\
\hline \multirow[t]{6}{*}{ Family } & $1^{\mathrm{st}}$ & 3.32 & - & & & 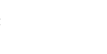 \\
\hline & $3 \mathrm{rd}$ & 3.10 & & - & & \\
\hline & $2^{\text {nd }}$ & 3.04 & & & - & \\
\hline & $4^{\text {th }}$ & 2.96 & & & & - \\
\hline & Year & $M$ & $1^{\mathrm{st}}$ & $3^{\mathrm{rd}}$ & $4^{\text {th }}$ & $2^{\text {nd }}$ \\
\hline & year & IVI & 3.50 & 3.37 & 3.25 & 3.17 \\
\hline \multirow{4}{*}{ Total degree } & $1^{\text {st }}$ & 3.50 & - & 0.13 & 0.25 & $0.33^{*}$ \\
\hline & $3^{\text {rd }}$ & 3.37 & & - & 0.12 & 0.20 \\
\hline & $4^{\text {th }}$ & 3.25 & & & - & 0.08 \\
\hline & $2^{\text {nd }}$ & 3.17 & & & & - \\
\hline
\end{tabular}




\section{Macrothink}

Results in table 8 showed the difference was in favour of the first year students and this result may attribute to the fact that these students pass by the second "adolescence" and it is a period of time characterized by sexual feelings and it is totally different from the secondary stage as they look at sex differently. While the third and fourth year students became more mature and they started to apply what they have acquired educationally during the educational stage about different topics and so their problems were less.

3. Achievement variable: means and standard deviations were calculated of the level of the problems facing the Jordanian universities' problems according to achievement variable as it is illustrated in table 9.

Table 9. Means and standard deviations were calculated of the level of the problems facing the Jordanian universities' problems according to achievement variable

\begin{tabular}{|c|c|c|c|c|}
\hline Field & Achievement & $\mathrm{N}$ & M & Std \\
\hline \multirow{4}{*}{$\begin{array}{l}\text { curricula and teaching methods and their } \\
\text { appropriateness to academic life }\end{array}$} & Low & 212 & 3.52 & 0.36 \\
\hline & Moderate & 125 & 3.11 & 0.39 \\
\hline & High & 69 & 3.19 & 0.31 \\
\hline & Total & 406 & 3.34 & 0.41 \\
\hline \multirow[t]{4}{*}{ personal, emotional and psychological relations } & Low & 212 & 3.45 & 0.33 \\
\hline & Moderate & 125 & 3.08 & 0.36 \\
\hline & High & 69 & 3.12 & 0.32 \\
\hline & Total & 406 & 3.28 & 0.39 \\
\hline \multirow[t]{4}{*}{ financial , living and professional status } & Low & 212 & 3.76 & 0.38 \\
\hline & Moderate & 125 & 3.51 & 0.45 \\
\hline & High & 69 & 3.49 & 0.38 \\
\hline & Total & 406 & 3.63 & 0.42 \\
\hline \multirow[t]{4}{*}{ health and physical growth } & Low & 212 & 3.22 & 0.51 \\
\hline & Moderate & 125 & 2.95 & 0.65 \\
\hline & High & 69 & 2.93 & 0.61 \\
\hline & Total & 406 & 3.09 & 0.59 \\
\hline \multirow[t]{5}{*}{ social and entertainment activity } & Low & 212 & 3.34 & 0.57 \\
\hline & Moderate & 125 & 2.72 & 0.44 \\
\hline & High & 69 & 2.94 & 0.30 \\
\hline & Total & 406 & 3.08 & 0.57 \\
\hline & Low & 212 & 3.23 & 0.52 \\
\hline \multirow[t]{4}{*}{ Family } & Moderate & 125 & 2.97 & 0.48 \\
\hline & High & 69 & 2.93 & 0.43 \\
\hline & Total & 406 & 3.10 & 0.51 \\
\hline & Low & 212 & 3.47 & 0.28 \\
\hline \multirow[t]{3}{*}{ Total degree } & Moderate & 125 & 3.11 & 0.28 \\
\hline & High & 69 & 3.15 & 0.26 \\
\hline & Total & 406 & 3.30 & 0.33 \\
\hline
\end{tabular}


It is noted that there were apparent means of the level of the problems which the Jordanian students suffer from according to the achievement variable as the students with low achievement got the highest mean (3.47)followed respectively by the students with high achievement with (3.15) and the students with moderate achievement (3.11) and to know whether the differences between the means were statistically significant at $(a \leq 0.05)$, ANOVA was used and the results were as follows.

Table 10. ANOVA for the differences in the level of the students' problems according to achievement level variable

\begin{tabular}{|c|c|c|c|c|c|c|}
\hline Field & Source of variance & Sum of seq. & $\mathrm{Fd}$ & Mean Seq. & $\mathrm{F}$ & Sig. \\
\hline \multirow{3}{*}{$\begin{array}{l}\text { curricula and teaching } \\
\text { methods and their } \\
\text { appropriateness to } \\
\text { academic life }\end{array}$} & Between groups & 14.632 & 2 & 7.316 & 54.932 & 0.000 \\
\hline & Within groups & 53.673 & 403 & 0.133 & & \\
\hline & Total & 68.305 & 405 & & & \\
\hline \multirow{3}{*}{$\begin{array}{l}\text { personal,emotional } \\
\text { and psychological } \\
\text { relations }\end{array}$} & Between groups & 13.423 & 2 & 6.712 & 57.915 & 0.000 \\
\hline & Within groups & 46.703 & 403 & 0.116 & & \\
\hline & Total & 60.127 & 405 & & & \\
\hline \multirow{3}{*}{$\begin{array}{l}\text { financial ,living and } \\
\text { professional status }\end{array}$} & Between groups & 6.548 & 2 & 3.274 & 20.371 & 0.000 \\
\hline & Within groups & 64.774 & 403 & 0.161 & & \\
\hline & Total & 71.322 & 405 & & & \\
\hline \multirow{3}{*}{$\begin{array}{l}\text { health and physical } \\
\text { growth }\end{array}$} & Between groups & 7.808 & 2 & 3.904 & 11.952 & 0.000 \\
\hline & Within groups & 131.634 & 403 & 0.327 & & \\
\hline & Total & 139.442 & 405 & & & \\
\hline \multirow{4}{*}{$\begin{array}{l}\text { social and } \\
\text { entertainment activity }\end{array}$} & Between groups & 31.876 & 2 & 15.938 & 65.68 & 0.000 \\
\hline & Within groups & 97.794 & 403 & 0.243 & & \\
\hline & Total & 129.67 & 405 & & & \\
\hline & Between groups & 7.652 & 2 & 3.826 & 15.684 & 0.000 \\
\hline \multirow[t]{3}{*}{ Family } & Within groups & 98.305 & 403 & 0.244 & & \\
\hline & Total & 105.957 & 405 & & & \\
\hline & Between groups & 12.018 & 2 & 6.009 & 77.397 & 0.000 \\
\hline \multirow[t]{2}{*}{ Total degree } & Within groups & 31.288 & 403 & 0.078 & & \\
\hline & Total & 43.306 & 405 & & & \\
\hline
\end{tabular}

Results in the previous table showed statistical significant differences at level $(a \leq 0.05)$ in the level of the problems which the Jordanian university students suffer from according to the achievement variable based on the value of the calculated $F(77.397)$ with $\operatorname{sig}(0.000)$ for the total degree. And there were statistical significant differences at level $(a \leq 0.05)$ in the level of the problems which the Jordanian university students suffer from according to the achievement variable in all the fields and to find out the significance of these differences, Scheffe's test post Hoc Comparisons was used. 
Table 11. Scheffe's test post Hoc Comparisons for differences in the level of the problems facing the Jordanian public universities' students according to the achievement variable

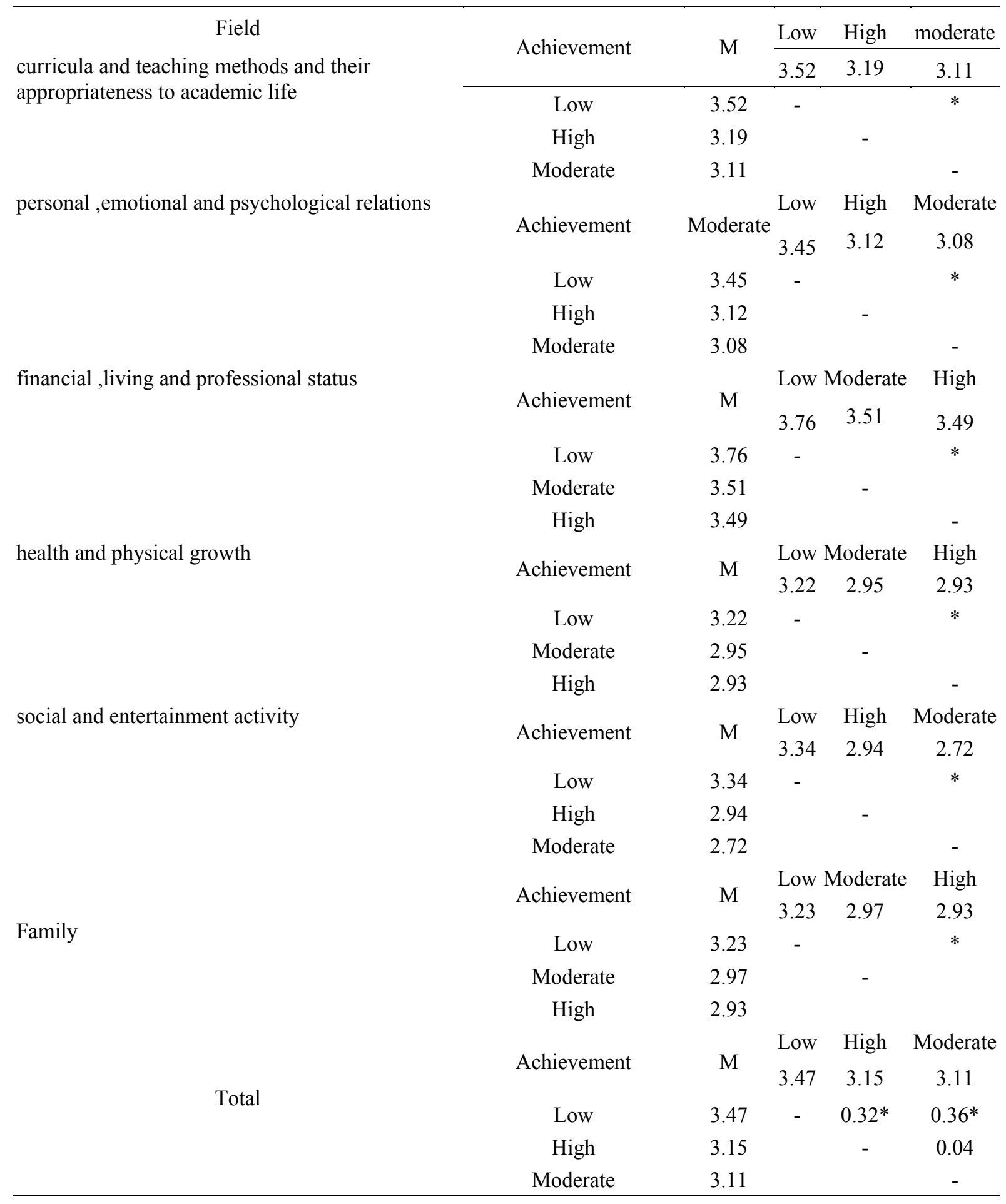

Results in the previous table showed the difference was in favour of the students with low achievement and this result may due to that those students look for more entertainment activities while the students with high achievement are more interested in studying and getting high grades. 


\section{Recommendations}

- Necessity to have educational guides and supervisors in the universities to solve academic, psychological, and social problems facing the students.

- Organizing educational programs for the students in the universities to aware them of the best educational and psychological techniques in achievement.

- Necessity to support and help the distinguished students financially and psychologically.

- Establishing a section for following up the students and their problems that may also include medical and psychological clinics.

\section{References}

Abo alia, M., \& Mahafda, S. (1997). Problems of Hashemite University students from the students' perspective. Studies of Educational Studies, 24(2), 329-340.

Adas, A., \& Tawq, M. (1996). Entrance into Psychology, Dar fikr for publishing \& distribution. Jordan, Amman.

Albana, Anwar \& Rib'I, A. (2006). Problems of Alaqsa University's students in Ghaza from the students' perspective. Journal of Islamic University, Series of human studies, 14(2), 505-537.

Al-kaid, K. (2003). Amman, financial, social and educational problems facing Private universities' students in Jordan, Unpublished thesis, College of high studies, University of Jordan.

Al-moshref, F, A. (2000). Problems of Sana` students and their counseling needs. Journal of Kuwait University, Educational Journal, 54(14), 169-207.

Altalm, Sh \& Ramzi, B. (1988). Problems of Yarmouk University students. Journal of Abhath Al-Yarmouk, 1(2), 128-129.

Alweida, S. (2005). Some problems facing Saudi students studying in the Jordanian universities. Derasat of Educational sciences, 32(1), 91-110.

Hamdi, N. (1998). Counseling in age stages, Open Jerusalem University publications. Jordan, Amman.

Hatab, Z., \& Abas, M. (1980). Change \& Youth, Institute of Arab Development. Lebanon, Beirut.

Heppner, P.P., Neal, G.W., \& Larson L. M. (1984). Problem solving training as prevention with college students. The Personal and Counseling Journal, 62(9), 514-519.

Lucas, M., \& Berkley, L. A. (2005). Counseling needs of students who seek help at a university counseling center: A closer look at gender and multicultural issue. Journal of 
College Students Development, 46(3), 251-266. http://dx.doi.org/10.1353/csd.2005.0029

Morgan, K. A. (2003). The social and Academic Adjustment of Students to College Life, WWW.Clearinghouse.Education

Murray, J. (1990). Reality, versus expectations: Do the expectation of news students correspond with their experience. Paper Presented at The Annual Forum of The Association for Institutional Research, 30, Louisville, KY, May 13 - 16.

Najm, S. (2002). Problems Facing the students of Education College at King Faisal University. Scientific Journal (Human sciences \&administration, 3(1), 137-176.

Rizq, A. (2008). Problems of the secondary stage's students and their counseling needs. Damascus Journal, 24(2), 14.

Sa dah, J., Zamil, M., \& Aboziada, I. (2002). Problems facing students in Najah University during Aqsa Entifada. Journal of Arab Universities Union, 1(40), 2.

Senile, P., Consuelo, A., Robin, B., \& Stewart, P. (2001). Adjustment issues of Turkish college student studying in the united states. College Students Journal, 35(1), 11-52.

Shaheen, M. (2009). Students' problems in Open Quds University. Journal of Arab Universities Union, 1(54), 1.

\section{Copyright Disclaimer}

Copyright for this article is retained by the author(s), with first publication rights granted to the journal.

This is an open-access article distributed under the terms and conditions of the Creative Commons Attribution license (http://creativecommons.org/licenses/by/3.0/). 